\title{
Soybeans Competitiveness With Morning GloRY ${ }^{1}$
}

\author{
Competitividade de Soja com Cordas-de-Viola
}

PICCININI, F. ${ }^{2}$, MARTIN, T.N. ${ }^{2}$, MACHADO, S.L.O. ${ }^{2}$, KRUSE, N.D. ${ }^{2}$, and SCHMATZ, R. ${ }^{2}$

\begin{abstract}
Weeds interfere negatively on development, yield and quality of soybeans (Glycine max). Inadequate weed control by herbicide use can select for resistant or tolerant biotypes, leading to a shift in the weed flora. An example is the increase of incidence of morning glory (Ipomoea spp.) in soybeans growing areas in South Brazil. The aim of this study was to determine the competitiveness of soybeans intercropped with $I$. triloba, I. indivisa and I. purpurea through a replacement experiments series. Greenhouse experiments were conducted in a completely randomized design with four replications. The first experiment was carried out aiming to get the plant population while total plant dry mass remained constant. Other experiments were done under replacement series experiments with soybeans and morning glory ratios of 100:0, 75:25, 50:50, 25:75 and 100:0 using the 250 plant $\mathrm{m}^{-2}$ defined by the preliminary experiment. Leaf area, root and shoots dry mass were assessed. Diagrams along with index interpretation were used to performed a competitiveness analysis. Soybeans showed greater competitiveness as I. triloba, I. purpurea and I. indivisa species for the leaf area, root and shoots dry mass variables. Intraspecific competition prevails between soybean plants whilst interspecific competition prevails for morning glory.
\end{abstract}

Keywords: competition, I. triloba, I. indivisa, I. purpurea, replacement series.

RESUMO - As plantas daninhas interferem negativamente no desenvolvimento, na produtividade e na qualidade da soja. O controle inadequado das plantas daninhas pelo uso de herbicidas pode selecionar biótipos resistentes e/ ou plantas tolerantes, provocando mudança na flora de plantas daninhas. Objetivou-se com este trabalho determinar a competitividade da soja em convivência com plantas de I. triloba, I. indivisa e I. purpurea, por meio de experimentos em série de substituição. Os experimentos foram realizados em casa de vegetação, no delineamento inteiramente casualizado com quatro repetições. $O$ primeiro experimento foi realizado com a finalidade de obter a população de plantas a partir da qual a massa seca total das plantas permanecesse constante; já os demais experimentos foram realizados em série de substituição com proporções entre soja e cordade-viola de 100:0, 75:25, 50:50, 25:75 e 100:0, com população definida no experimento preliminar de 250 plantas $\mathrm{m}^{-2}$. As variáveis avaliadas foram área foliar, massa de matéria seca de raiz e massa de matéria seca da parte aérea. A análise da competitividade foi feita por diagramas de competitividade e por interpretações dos indices. Os resultados indicam a soja como competidor superior às espécies de cordas-de-viola (I. triloba, I. indivisa e I. purpurea) para as variáveis área foliar, massa de matéria seca de raize massa de matéria seca da parte aérea e que para soja predomina a competição intraespecífica, enquanto para as cordas-de-viola prevalece a competição interespecífica.

Palavras-chave: competição, I. triloba, I. indivisa, I. purpurea, série de substituição.

Recebido para publicação em 26.7.2015 e aprovado em 13.10.2015.

Universidade Federal de Santa Maria, Santa Maria, Rio Grande do Sul, Brasil, <martin.ufsm@gmail.com>.

Planta Daninha, Viçosa-MG, v. 34, n.1, p. 25-33, 2016 


\section{INTRODUCTION}

Weeds, being naturally occurring species, have greater ability to compete with cultivated species. This is because they have genetic variability, ensuring greater ability to adapt to the competitive environment than selected species (Bianchi et al., 2006). Thus, competition is a form of negative interference, in which individuals compete for shared resources, such as nutrients, physical space, water and light, and it can occur below or above ground (Casper \& Jackson, 1997; Berger et al., 2008). When there is competition for environmental resources that are in short supply, there will be growth reduction and elimination of less adapted species (Fleck et al., 2009).

One of the main factors responsible for the reduction in soybeans grain yield is the competition with weeds (Agostinetto et al., 2009), which may also be a host of pests, pathogens, nematodes and make it difficult to perform cultivation and harvesting (Monquero et al., 2014). Furthermore, the presence of weeds can affect the quality of seeds, particularly the protein and oil content, increasingly important parameters to determine soybeans economic value (Millar et al., 2011). Although weeds cause damage to crops, soybeans have a higher competitive ability, and this is attributed to some growth characteristics inherent in the improvement of cultivars, including emergence speed, plant height, canopy architecture, dry matter accumulation and plants spatial arrangement (Shaw et al., 1997; Place et al., 2011).

The study of competitive interactions among weeds and crops is critical in the foundation of management recommendations. To determine the competitive potential of weeds, appropriate experimental design and analysis methods are required (Roush et al., 1989). A suitable alternative for studies of this magnitude is the use of experiments in series of replacement, for they allow the determination of which species or biotype is more competitive and, consequently, if the competition is inter- or intraspecific (Cousens, 1991). In these experiments, the ratio of each of the genotypes varies, while the total population remains constant (Radosevich et al., 2007).

Planta Daninha, Viçosa-MG, v. 34, n. 1, p. 25-33, 2016
Morning glory are annual plants. They belong to the Convolvulaceae family and produce an average of 300 seeds per plant. Seeds present dormancy with emergence flows occurring from spring to summer, and the biological cycle is higher in comparison with soybeans cultivars. In recent years, the importance of morning glory has increased mainly because of the difficulty of control when applying herbicide glyphosate because of tolerance to this herbicide (Galon et al., 2013).

Knowledge of soybeans competitive ability in relation to the species of morning glory (Ipomoea spp.) by the use of replacement experiments allows to establish the influence of weed populations on the crop and the ratio of species in order to understand the competitive relationships, making it possible to develop more effective strategies in the control. Thus, under the hypothesis that there is a difference in competitive ability of species of morning glory in coexistence with soybeans, the aim of this study was to determine the competitive ability of soybeans intercropped with species of morning glory I. triloba, I. indivisa and I. purpurea.

\section{MATERIAL AND METHODS}

The experiments were conducted in a greenhouse from October 2013 to January 2014. Polyethylene pots with capacity of $8 \mathrm{dm}^{3}$ and $25 \mathrm{~cm}$ high were used, filled with superficial layer soil classified as sandy Dystrophic Red Ultisol (Embrapa, 2006). Chemical analysis of the soil was held, which was corrected with $\mathrm{P}_{2} \mathrm{O}_{5}$ and $\mathrm{K}_{2} \mathrm{O}$ according to technical indications for soybeans crops (Reunião... 2012). The experimental design was completely randomized with four replications. For greater homogeneity among experimental units, changes were weekly made in the pot positions.

The first experiment was in an additive series, using soybeans and morning glory monocultures to obtain the population of plants $\mathrm{m}^{-2}$, from which dry matter of shoots (SDMM) per area unit $\left(\mathrm{g} \mathrm{m}^{-2}\right)$ becomes independent of the population, according to the "constant final production law" (Radosevich et al., 2007). Populations tested were 1, 2, 4, 8,16 and 32 plants pot ${ }^{-1}$, equivalent to 37,74 , 
$148,296,592$ and 1,184 plants $\mathrm{m}^{-2}$ soybeans, respectively, as well as for morning glory species. At 30 days after emergence (DAE), aerial parts of the plants were collected, which were dried at an oven at $60{ }^{\circ} \mathrm{C}$ for 72 hours. To obtain the constant final production, eight plants per pot were considered, equivalent to approximately 250 plants $\mathrm{m}^{2}$.

The second experiment in a replacement series consisted of five ratios (100:0, 75:25, $50: 50, \quad 25: 75$ and 0:100\%) between soybeans and the three species of morning glory (I. triloba, I. indivisa and I. purpurea), representing, respectively, 8:0, 6:2, 4:4, 2:6 and 0:8 plants per pot. Preceding sowing, seed treatment was conducted with fipronil + pyraclostrobin at a dose of $100 \mathrm{~g}$ a.i. per $100 \mathrm{~kg}$ of seeds. The reagent soybeans cultivar was TEC6029, presenting as characteristic indeterminate type of growth, average/tall plant height, early maturity and maturity group 6.0. Morning glory seeds were collected in a crop area in the Brazilian municipality of Santa Maria (29॰42'51"S and 53॰44'00"O).

Soybeans seeds were sown $3 \mathrm{~cm}$ deep in the pots, while the morning glory seeds were first sown in trays of 128 cells filled with soil after being subjected to the process of overcoming dormancy by mechanical scarification. Seedling emergence of the species of morning glory occurred on the same emergence day of the ones of soybeans and their transplant to the pots was held four days later.

At 50 days after emergence (DAE) of soybeans and morning glory, the following variables were evaluated: leaf area $\left(\mathrm{LA}, \mathrm{cm}^{2}\right)$ done by scanning (300 dpi) of all plants leaves and calculated with software QUANT V.1.0.1 (Vale et al., 2001), root dry matter mass (RDMM, g per plant), in which soil was removed from the roots with water for further drying in an oven with forced air circulation at $60{ }^{\circ} \mathrm{C}$ to constant weight, as well as for the shoot dry matter mass (SDMM, $\mathrm{g} \mathrm{m}^{-2}$ ). For analysis of the variables, the method of graphical or conventional analysis was used for replacement experiments, which consists of the construction of diagrams based on the relative productivity (RP) and relative yield total (RYT) (Roush et al., 1989; Cousens, 1991).
Relative yields were calculated by the formulas: $\mathrm{RPa}=(\mathrm{p})(\mathrm{Amix} / \mathrm{Amon}), \mathrm{RPb}=(1-\mathrm{p})$ (Bmix/Bmon) and $\mathrm{RYT}=\mathrm{RPa}+\mathrm{RPb}$, where: $\mathrm{RPa}=$ relative productivity of the species " $\mathrm{a}$ " (soybeans); $\mathrm{RPb}=$ relative productivity of the species " $b$ " (morning glory); $p=$ ratio of " $a$ " in $\%$ divided by 100; Amix = value of the variable to be analyzed of "a" in a mix; Amon = value of the variable to be analyzed of " $a$ " in monoculture; $\mathrm{Bmix}=$ value of the variable to be analyzed ob "b" in a mix; Bmon = value of the variable to be analyzed of " $b$ " in a monoculture; and RYT = relative yield total (Hoffman \& Buhler, 2002). Thereafter, the indexes were estimated: CG (comparative growth) representing respectively the comparative growth of species "a" in relation to species "b", K (relative dominance) relative dominance of one species over the other and A (more competitive species). These indexes were calculated in the ratio of $50 \%$ of soybean plants and of each species of morning glory (Cousens, 1991).

Data from differences in competitiveness indexes, DRT and RYT, in relation to the hypothetical straight lines in the respective ratios $(75,50$ and $25 \%)$ were submitted to analysis of variance by the F-test and the averages were compared by the t-test (Hoffman \& Buhler, 2002). When significant, mean of variables LA, RDMM and SDMM were compared by Dunnett's test, considering monocultures as controls. Analyses were performed using the statistical software SAS (Statistical Analysis System version 8.0) $(\mathrm{p} \leq 0.05)$.

\section{RESULTS AND DISCUSSION}

In replacement experiments (Figure 1), the deviations of straight lines of relative productivity (RP) in relation to the expected straight lines for variables leaf area (LA), root dry matter mass (RDMM) and shoot dry matter mass (SDMM) in soybeans and in species of morning glory were represented by convex and concave lines, respectively. These results indicate that both species compete for the same resources, and one is more competitive than the other. In this case, soybeans were more competitive by the available resources than the species of the genus Ipomoea studied, 
corroborating Agostinetto et al. (2013) and Wandscheer et al. (2013), which also found them to be a more competitive culture than weeds.

Overall, there was a difference for RP and $\mathrm{PRC}$ between the ratios of soybean plants and morning glory (Table 1). For variable FA, RYD differed in all ratios of soybeans in combination with species $I$. triloba and I. indivisa, unlike soybeans in combination with I. purpurea, which differed only in the ratio 25:75. However, although decline has indeed been observed compared to the
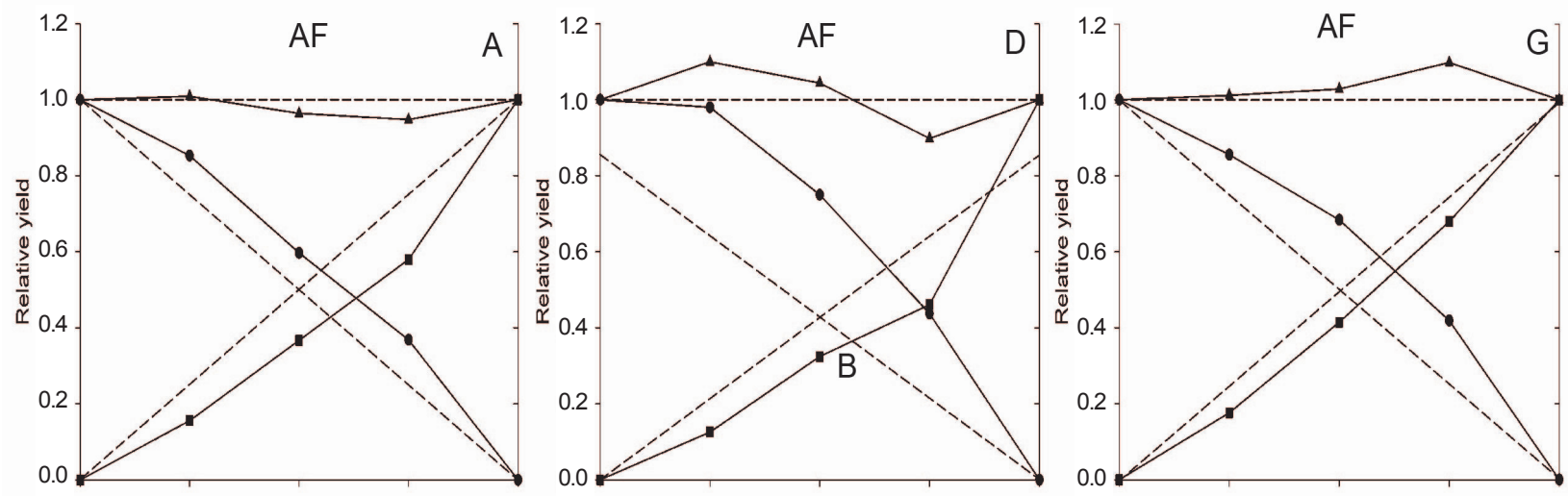

MMSR
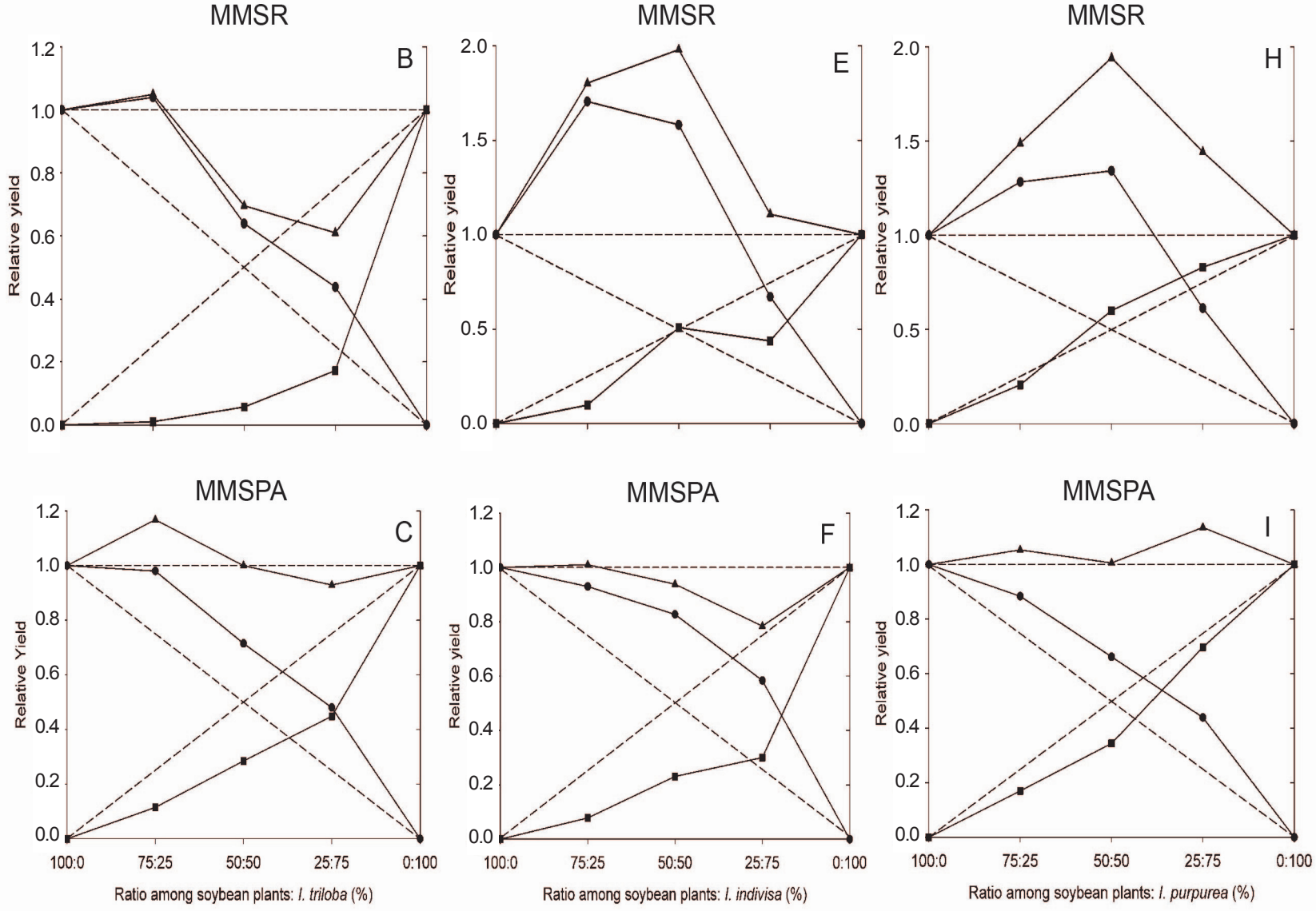

Figure 1 - Relative yield of soybeans $(\bullet)$ and of morning glory $(\boldsymbol{\square})$ and relative yield total $(\mathrm{RYT})(\boldsymbol{\Delta})$ regarding leaf area (A, D and G), root dry matter mass (RDMM) (B, E and H) and shoot dry matter mass (SDMM) (C, F and I) depending of the ratios among the species. Dashed lines refer to the hypothetical relative yield, when there is no interference from one species over another. 
Table 1 - Relative yield differences (RYD) and relative yield total (RYT) for variables leaf area, root dry matter mass (RDMM) and shoot dry matter mass (SDMM), in ratios of soybean plants with I. triloba, I. indivisa and I. purpurea

\begin{tabular}{|c|c|c|c|}
\hline \multirow{3}{*}{ Characteristic } & \multicolumn{3}{|c|}{ Ratio of soybean plants: I. triloba } \\
\hline & $75: 25$ & $50: 50$ & $25: 75$ \\
\hline & \multicolumn{3}{|c|}{ Leaf area } \\
\hline Soybeans RYD & $0.10 \pm 0.01 *$ & $0.1 \pm 0.02 *$ & $0.12 \pm 0.00 *$ \\
\hline I. triloba $R Y D$ & $-0.09 \pm 0.01 *$ & $-0.13 \pm 0.02 *$ & $-0.17 \pm 0.04^{*}$ \\
\hline \multirow[t]{2}{*}{ RYT } & $1.01 \pm 0.01^{\mathrm{ns}}$ & $0.96 \pm 0.04^{\mathrm{ns}}$ & $0.95 \pm 0.05^{\mathrm{ns}}$ \\
\hline & \multicolumn{3}{|c|}{ Root dry matter mass (RDMM) } \\
\hline Soybeans RYD & $0.64 \pm 0.03 *$ & $0.78 \pm 0.09 *$ & $1.50 \pm 0.09^{*}$ \\
\hline I. triloba $R Y D$ & $-0.21 \pm 0.00 *$ & $-0.39 \pm 0.01 *$ & $-0.52 \pm 0.01^{*}$ \\
\hline \multirow[t]{2}{*}{ RYT } & $1.43 \pm 0.04 *$ & $1.39 \pm 0.08^{*}$ & $1.98 \pm 0.08^{*}$ \\
\hline & \multicolumn{3}{|c|}{ Shoot dry matter mass (SDMM) } \\
\hline Soybeans RYD & $0.30 \pm 0.01 *$ & $0.21 \pm 0.05^{*}$ & $0.23 \pm 0.04^{*}$ \\
\hline I. triloba $R Y D$ & $-0.13 \pm 0.01 *$ & $-0.22 \pm 0.02 *$ & $-0.30 \pm 0.04 *$ \\
\hline \multirow[t]{3}{*}{ RYT } & $1.17 \pm 0.02 *$ & $1.0 \pm 0.04^{\mathrm{ns}}$ & $0.93 \pm 0.07^{\mathrm{ns}}$ \\
\hline & \multicolumn{3}{|c|}{ Ratios of soybean plants: I. indivisa } \\
\hline & \multicolumn{3}{|c|}{ Leaf area } \\
\hline Soybeans RYD & $0.46 \pm 0.07 *$ & $0.25 \pm 0.05^{*}$ & $0.19 \pm 0.02 *$ \\
\hline I. indivisa $R Y D$ & $-0.12 \pm 0.00 *$ & $-0.18 \pm 0.03 *$ & $-0.29 \pm 0.06^{*}$ \\
\hline \multirow[t]{2}{*}{ RYT } & $1.34 \pm 0.07 *$ & $1.07 \pm 0.04^{\mathrm{ns}}$ & $0.90 \pm 0.05^{\mathrm{ns}}$ \\
\hline & \multicolumn{3}{|c|}{ Root dry matter mass (RDMM) } \\
\hline Soybeans RYD & $0.95 \pm 0.08^{*}$ & $1.08 \pm 0.08^{*}$ & $0.42 \pm 0.07^{*}$ \\
\hline I. indivisa $R Y D$ & $-0.15 \pm 0.01 *$ & $0.01 \pm 0.07^{\mathrm{ns}}$ & $-0.31 \pm 0.07 *$ \\
\hline \multirow[t]{2}{*}{ RYT } & $1.80 \pm 0.09 *$ & $2.09 \pm 0.05^{*}$ & $1.11 \pm 0.06^{\mathrm{ns}}$ \\
\hline & \multicolumn{3}{|c|}{ Shoot dry matter mass (SDMM) } \\
\hline Soybeans RYD & $0.47 \pm 0.05^{*}$ & $0.43 \pm 0.06^{*}$ & $0.33 \pm 0.06^{*}$ \\
\hline I. indivisa $R Y D$ & $-0.17 \pm 0.01 *$ & $-0.27 \pm 0.03 *$ & $-0.45 \pm 0.05^{*}$ \\
\hline \multirow[t]{3}{*}{ RYT } & $1.30 \pm 0.30 *$ & $1.16 \pm 0.07^{\mathrm{ns}}$ & $0.88 \pm 0.09^{\mathrm{ns}}$ \\
\hline & \multicolumn{3}{|c|}{ Ratio of soybean plants: I. purpurea } \\
\hline & \multicolumn{3}{|c|}{ Leaf area } \\
\hline Soybeans RYD & $0.11 \pm 0.06^{\mathrm{ns}}$ & $0.18 \pm 0.09^{\mathrm{ns}}$ & $0.17 \pm 0.04^{*}$ \\
\hline I. purpurea RYD & $0.07 \pm 0.03^{\mathrm{ns}}$ & $-0.09 \pm 0.05^{\mathrm{ns}}$ & $-0.07 \pm 0.03^{\mathrm{ns}}$ \\
\hline \multirow[t]{2}{*}{ RYT } & $1.03 \pm 0.08^{\mathrm{ns}}$ & $1.10 \pm 0.14^{\mathrm{ns}}$ & $1.10 \pm 0.07^{\mathrm{ns}}$ \\
\hline & \multicolumn{3}{|c|}{ Root dry matter mass (RDMM) } \\
\hline Soybeans RYD & $0.53 \pm 0.03 *$ & $0.84 \pm 0.20 *$ & $0.36 \pm 0.16^{\mathrm{ns}}$ \\
\hline I. purpurea RYD & $-0.04 \pm 0.03^{\mathrm{ns}}$ & $0.10 \pm 0.08^{\mathrm{ns}}$ & $0.08 \pm 0.07^{\mathrm{ns}}$ \\
\hline \multirow[t]{2}{*}{ RYT } & $1.49 \pm 0.06^{*}$ & $1.94 \pm 0.23 *$ & $1.44 \pm 0.22^{\mathrm{ns}}$ \\
\hline & \multicolumn{3}{|c|}{ Shoot dry matter mass (SDMM) } \\
\hline Soybeans RYD & $0.13 \pm 0.04 *$ & $0.16 \pm 0.04 *$ & $0.19 \pm 0.05^{*}$ \\
\hline I. purpurea $R Y D$ & $-0.08 \pm 0.02 *$ & $-0.16 \pm 0.01 *$ & $-0.05 \pm 0.04^{\mathrm{ns}}$ \\
\hline RYT & $1.05 \pm 0.05^{\mathrm{ns}}$ & $1.01 \pm 0.05^{\mathrm{ns}}$ & $1.14 \pm 0.09^{\mathrm{ns}}$ \\
\hline
\end{tabular}

ns Nonsignificant; * significant by the t-test $(\mathrm{p} \leq 0.05)$. 
hypothetical straight lines of RYT (Figure 1, ADG), there was a significant difference ( $\mathrm{p} \leq 0.05$ ) only for the ratio of $75: 25$ of soybeans with $I$. indivisa.

For variable RDMM, RP and RYT differed statistically $(\mathrm{p} \leq 0.05)$ in all ratios between soybeans and I. triloba. As for the association of soybeans and I. indivisa, soybeans RP was significant in all ratios and $I$. indivisa RP differed in ratios 75:25 and 25:75, and RYT statistically differed in ratios 75:25 and 50:50. When in association with I. purpurea, soybeans RP and RYT were significant and responded positively only in ratios 75:25 and 50:50.

As for variable SDMM, the response for $\mathrm{RP}$ was similar for the soybeans associations with I. triloba and I. indivisa, significantly differing in the three ratios and for RYT only at ratio 75:25. With $I$. purpurea, soybeans RP statistically differed in all plants ratios. However, I. purpurea RP differed only in 75:25 and 50:50 and RYT did not differ in any ratio.

RYT values less than 1 , corresponding to a concave line, mean that there is damage in the growth of both species. For RYT higher than 1 , a convex line is obtained, indicating that competition is prevented, because the supply of resources exceeds demand or because the species have different demands from the environment. The highest relative yield total (RYT) compared to what is expected reflects the behavior that demonstrates that a species is more aggressive than the other and contributes to total yield more than what is expected (Radosevich, 1987). According to Rizzardi et al. (2004), the reduction in soybean biomass is more intense when in the presence of morning glory (Ipomoea ramosissima) than milkweed (Euphorbia heterophylla) and this is aggravated in situations in which the weed is established prior to culturing. When in mixed infestation, the authors have found that Ipomoea ramosissima was more competitive than milkweed.

Importantly, weed interference in soybeans varies with the farming system, weather conditions of the place, plant flora composition, population by area and present in the area, number of plants per area and, especially, competition time. Thus, initial development characteristics of each cultivar are crucial, and it is in the growing season that the definitive relationships of competition are generally set out (Lamego et al., 2005).

Carvalho et al. (2011), in a study of wheat and plantain signalgrass (Urochloa plantaginea), have shown that plantain signalgrass was more sensitive to intraspecific competition than wheat, and uncompetitive when compared to wheat. Wandscheer et al. (2013) have shown that soybeans have a competitive ability equivalent to that of Indian goosegrass (wiregrass, crowfootgrass) (Eleusine indica). However, this poaceae was more competitive except when evaluating plant height. For Yamauti et al. (2011), triticale (a hybrid of wheat (Triticum) and rye (Secale)) was more competitive than wild radish (Raphanus raphanistrum). In general, in replacement experiments, where cultures express greater competition than weeds, this ability is attributed to the lower level of infestation of these plants (Vilá et al., 2004).

Table 2 shows competitiveness indexes of $\mathrm{CG}, \mathrm{K}$ and $\mathrm{A}$ between soybeans and the three species of the genus Ipomoea. When soybeans and $I$. triloba are in competition, the indexes differed significantly ( $\mathrm{p} \leq 0.05)$ for LA and SDMM variables, and for RDMM there was significance for indexes $\mathrm{CG}$ and $\mathrm{A}$. The relative competitiveness $(\mathrm{RC}>1)$ indicates that soybeans surpassed I. triloba, showing that the culture has dominance over the weed. The same behavior was observed for indexes $\mathrm{K}$ and $\mathrm{A}$, where $(\mathrm{Ks}>\mathrm{Kc})$, and characterized that soybeans dominated regarding weeds and $(A>0)$, being more competitive. In the soybeans and $I$. indivisa competition there were significant differences for indexes CG and $A$ in variables LA and RDMM. For variable SDMM there were differences in the three indexes. In the experiment between soybeans and I. purpurea, indexes $\mathrm{CG}$ and A were significant for variable LA. For RDMM there was significance for CG and K, unlike SDMM, where only index A was significant and indicated that soybeans were more competitive regarding weeds. Thus, the interpretation of the competitiveness indexes corroborates the results obtained in the graphical analysis, indicating that soybeans are more competitive than the species of the genus Ipomoea. 
Table 2 - Competitiveness indexes between soybeans and morning glory, expressed by relative competitiveness (RC), relative clustering coefficient $(\mathrm{K})$ and of aggressivity (A) for variables leaf area (LA, $\mathrm{cm}^{2}$ per plant), root dry matter mass (RDMM, g per plant) and shoot dry matter mass (SDMM, g per plant)

\begin{tabular}{|l|c|c|c|c|}
\hline \multicolumn{1}{|c|}{ Variable } & CG & K s = soybeans & K c = I. triloba & A \\
\hline LA & $1.63 \pm 0.04^{*}$ & $1.50 \pm 0.11^{*}$ & $0.58 \pm 0.04$ & $0.23 \pm 0.01^{*}$ \\
\hline RDMM & $11.41 \pm 1.10^{*}$ & $-15.20 \pm 11.44^{\text {ns }}$ & $0.12 \pm 0.00$ & $1.17 \pm 0.09^{*}$ \\
\hline SDMM & $2.55 \pm 0.29^{*}$ & $2.84 \pm 0.72^{*}$ & $0.40 \pm 0.03$ & $0.43 \pm 0.05^{*}$ \\
\hline & CG & K s $=$ soybeans & K c = I. indivisa & A \\
\hline LA & $2.38 \pm 0.29^{*}$ & $3.63 \pm 1.09^{\text {ns }}$ & $0.49 \pm 0.05$ & $0.43 \pm 0.07^{*}$ \\
\hline RDMM & $4.27 \pm 0.71^{*}$ & $2.76 \pm 4.85^{\text {ns }}$ & $0.30 \pm 0.04$ & $0.70 \pm 0.06^{*}$ \\
\hline SDMM & $3.38 \pm 0.68^{*}$ & $-2.84 \pm 0.29^{*}$ & $1.13 \pm 0.26$ & $1.07 \pm 0.14^{*}$ \\
\hline & CG & K s $=$ soybeans & K c $=I . p u r p u r e a$ & A \\
\hline LA & $1.64 \pm 0.04^{*}$ & $5.53 \pm 4.01^{\text {ns }}$ & $0.74 \pm 0.15$ & $0.27 \pm 0.05^{*}$ \\
\hline RDMM & $1.92 \pm 0.07^{*}$ & $2.08 \pm 0.34^{*}$ & $0.52 \pm 0.02$ & $0.32 \pm 0.03^{*}$ \\
\hline SDMM & $2.35 \pm 0.50^{\text {ns }}$ & $-3.61 \pm 7.65^{\text {ns }}$ & $1.81 \pm 0.57$ & $0.74 \pm 0.2^{*}$ \\
\hline
\end{tabular}

ns Nonsignificant; * significant by the t-test $(\mathrm{p} \leq 0.05)$.

Table 3 - Soybeans response to the interference of I. triloba, I. indivisa and I. purpurea at 50 days after emergence for variables leaf area (LA, $\mathrm{cm}^{2}$ per plant), root dry matter mass (RDMM, g per plant) and shoot dry matter mass (SDMM, g per plant)

\begin{tabular}{|c|c|c|c|c|c|c|c|}
\hline \multirow{2}{*}{ Variable } & \multirow{2}{*}{ Specie } & \multicolumn{6}{|c|}{ Ratios of soybean plants: I. triloba } \\
\hline & & 100:0 & $75: 25$ & $50: 50$ & $25: 75$ & $0: 100$ & $\mathrm{CV}(\%)$ \\
\hline \multirow{2}{*}{ LA } & Soybeans & 199.41 & $226.83^{*}$ & $238.21 *$ & $293.67 *$ & - & 4.53 \\
\hline & I. triloba & - & $105.48^{*}$ & $124.31 *$ & $130.98 *$ & 169.43 & 9.41 \\
\hline \multirow{2}{*}{ RDMM } & Soybeans & 0.47 & $0.86^{*}$ & $1.20 *$ & $3.29 *$ & - & 12.53 \\
\hline & I. triloba & - & $0.27 *$ & $0.39 *$ & $0.53 *$ & 1.73 & 5.95 \\
\hline \multirow{2}{*}{ SDMM } & Soybeans & 1.40 & $1.97 *$ & $2.01 *$ & $2.70 *$ & - & 12.11 \\
\hline & I. triloba & - & $0.56^{*}$ & $0.70 *$ & $0.73 *$ & 1.23 & 15.86 \\
\hline & & \multicolumn{6}{|c|}{ Ratios of soybean plants: I. indivisa } \\
\hline \multirow{2}{*}{ LA } & Soybeans & 199.41 & $321.79^{*}$ & $299.08^{*}$ & $348.83 *$ & - & 11.06 \\
\hline & I. indivisa & - & $131.52 *$ & $170.37 *$ & $161.45^{*}$ & 262.71 & 17.54 \\
\hline \multirow{2}{*}{ RDMM } & Soybeans & 0.47 & $1.06^{*}$ & $1.48^{*}$ & $1.26^{*}$ & - & 15.61 \\
\hline & I. indivisa & - & $0.16^{*}$ & $0.41 \mathrm{~ns}$ & $0.23 *$ & 0.40 & 19.2 \\
\hline \multirow{2}{*}{ SDMM } & Soybeans & 1.40 & $2.29 *$ & $2.61 *$ & $3.29 *$ & - & 15.33 \\
\hline & I. indivisa & - & $0.64 *$ & $0.95^{*}$ & $0.82 *$ & 2.06 & 21.58 \\
\hline & & \multicolumn{6}{|c|}{ Ratios of soybean plants: I. purpurea } \\
\hline \multirow{2}{*}{ LA } & Soybeans & 199.41 & $193.31^{\mathrm{ns}}$ & $206.75^{\mathrm{ns}}$ & $283.90 *$ & - & 15.38 \\
\hline & I. purpurea & - & $210.64^{*}$ & $249.37^{*}$ & $299.81^{\text {ns }}$ & 356.00 & 13.85 \\
\hline \multirow{2}{*}{ RDMM } & Soybeans & 0.47 & $0.80^{\text {ns }}$ & $1.26^{*}$ & $1.15^{*}$ & - & 18.32 \\
\hline & I. purpurea & - & $0.74^{\mathrm{ns}}$ & $1.08^{\mathrm{ns}}$ & $0.99^{\text {ns }}$ & 0.90 & 22.08 \\
\hline \multirow{2}{*}{ SDMM } & Soybeans & 1.40 & $1.65 *$ & $1.91^{*}$ & $2.72 *$ & - & 5.76 \\
\hline & I. purpurea & - & $1.60 *$ & $1.62 *$ & $2.19^{\mathrm{ns}}$ & 2.36 & 14.13 \\
\hline
\end{tabular}

* Significant by the Dunnett's test $(\mathrm{p} \leq 0.05)$; ${ }^{\text {ns }}$ Nonsignificant. 
Comparing the interaction between soybeans and the species of morning glory in the ratios of 75,50 and $25 \%$ with the one of $100 \%$, which represents their monoculture, it was found that there was a significant difference by the Dunnett's test $(p \leq 0.05)$ for the variables evaluated (Table 3 ). The highest mean of LA, RDMM and SDMM per soybean plant was found in the ratio of 25:75. For the species of morning glory there was a reduction in the variables productivity when there was an increase in the ratio of soybean plants, where the lower means were found in the ratio of $75: 25$. This result shows that for soybeans intraspecific competition was crucial to reduce the average relative of the variables studied, unlike the species $I$. triloba, I. indivisa and I. purpurea, where interspecific competition was more important. According to Woldeamlak et al. (2001), cultures seeded in association with weeds wherein the ratio of plants is varied usually have an advantage in relative productivity. For Agostinetto et al. (2013), the increased competitiveness of one species over another suggests that it will have better capacity to absorb the resources of the ecological niche and thus greater potential for growth and development because of the greater amount of resources used.

Summarizing the results of this study, it is found that soybeans proved to be a better competitor than morning glory, benefiting from the presence of these Ipomoea in the capture of the environment resources with greater efficiency, and that intraspecific competition prevails, whereas for morning glory interspecific competition prevails.

\section{LITERATURE CITED}

AGOSTINETTO, D. et al. Competitividade relativa da soja em convivência com papuã (Brachiaria plantaginea).

Sci. Agr., v. 10, n. 3, p. 185-190, 2009.

AGOSTINETTO, D. et al. Habilidade competitiva relativa de milhã em convivência com arroz irrigado e soja. Pesq.

Agropec. Bras., v. 48, n. 10, p. 1315-1322, 2013.

BERGER, U. et al. Competition among plants: concepts, individual-based modeling approaches, and a proposal for a future research strategy. Persp. Plant Ecol. Evol. Syst., v. 9, n. 3-4, p. 121-135, 2008.

Planta Daninha, Viçosa-MG, v. 34, n. 1, p. 25-33, 2016
BIANCHI, M. A.; FLECK, N. G.; LAMEGO, F. P. Proporção entre plantas de soja e plantas competidoras e as relações de interferência mútua. Ci. Rural, v. 36, n. 5, p. 1380-1387, 2006.

CARVALHO, L. B.; ALVES, P. L. C. A.; MARTINS, J. V. F. Effects of plant density and proportion on the interaction between wheat with alexandergrass plants. Bragantia, v. 70, n. 1, p. 40-45, 2011.

CASPER, B. B.; JACKSON, R. B. Plant competition underground. Ann Rev Ecol. Syst., v. 28, n. 1, p. 545-570, 1997.

COUSENS, R. Aspects of the design and interpretation of competition (interference) experiments. Weed Technol., v. 5, n. 3, p. 664-673, 1991.

EMPRESA BRASILEIRA DE PESQUISA AGROPECUÁRIA - EMBRAPA. Centro Nacional de Pesquisa Agropecuária de Solos. Sistema brasileiro de classificação de solo. Rio de Janeiro: Embrapa Solos, 2006. $306 \mathrm{p}$.

FLECK, N. G. et al. Associação de características de planta em cultivares de aveia com habilidade competitiva.

Planta Daninha, v. 27, n. 2, p. 211-220, 2009.

GALON, L. et al. Glyphosate translocation in herbicide tolerant plants. Planta Daninha, v. 31, n. 1, p. 193-201, 2013.

HOFFMAN, M. L.; BUHLER, D. D. Utilizing sorghum as a functional model of crop-weed competition. I. Establishing a competitive hierarchy. Weed Sci., v. 50, n. 4, p. 466-472, 2002.

LAMEGO, F. P. et al. Tolerância à interferência de plantas competidoras e habilidade de supressão por cultivares de soja - I. Resposta de variáveis de crescimento. Planta Daninha, v. 23, n. 3, p. 405-414, 2005.

MONQUERO, P. A. et al. Absorção, translocação e metabolismo do glyphosate por plantas tolerantes e suscetíveis a este herbicida. Planta Daninha, v. 22, n. 3, p. 445-451, 2004.

MILLAR, K. D. L. et al. Evaluation of physiological parameters for the prediction of seed yield and quality for soybean (Glycine max) plants grown in the presence of weed competition. Plant Biosyst., v. 145, n. 1, p. 1-11, 2011.

PLACE, G. T. et al. Identifying soybean traits of interest for weed competition. Crop Sci., v. 51, n. 6, p. 2642-2654, 2011.

RADOSEVICH, S. R. Methods to study interactions among crops and weeds. Weed Technol., v. 1, n. 3, p. 190-198, 1987. 
RADOSEVICH, S. R.; HOLT, J. S.; GHERSA, C. M. Ecology of weeds and invasive plants: Relationship to agriculture and natural resource management. 3. ed. Hoboken: John Wiley \& Sons, 2007. 475 p.

RIZZARDI, M. A. et al. Interferência de populações de Euphorbia heterophylla e Ipomoea ramosissima isoladas ou em misturas sobre a cultura de soja. Planta Daninha, v. 22, n. 1, p. 29-34, 2004.

REUNIÃO DE PESQUISA DE SOJA DA REGIÃO SUL. Indicações técincas para a cultura da soja no Rio Grande do Sul e Santa Catarina, safras 2012/2013 e 2013/2014. In: REUNIÃO DE PESQUISA DE SOJA DA REGIÃO SUL, 29. Passo Fundo: Embrapa Trigo, 2012. p. 142.

ROUSH, M. L. et al. A comparison of methods for measuring effects of density and proportion in plant competition experiments. Weed Sci., v. 37, n. 2, p. 268-275, 1989.

SHAW, D. R. et al. Sicklepod (Senna obtusifolia) interference with soybean (Glycine max) cultivars following herbicide treatments. Weed Technol., v. 11, n. 3, p. 510-514, 1997.
VALE, F. X. R. et al. Quantificação de doenças - Quant: versão 1.0.1. Viçosa, MG: UFV, 2001. Software.

VILÁ, M.; WILLIAMSON, M.; LONSDALE, M. Competition experiments on alien weeds with crops: lessons for measuring plant invasion impact? Biol. Invas., v. 6, n. 1, p. 59-69, 2004.

WANDSCHEER, A. C. D. et al. Competitividade de capimpé-de-galinha com soja. Ci. Rural, v. 43, n. 12, p. 2125-2135, 2013.

WOLDEAMLAK, A.; BASTIAANS, L.; STRUIK, P. C. Competition and niche differentiation in barley (Hordeum vulgare) and wheat (Triticum aestivum) mixtures under rainfed conditions in the Central Highlands of Eritrea. Nether. J. Agric. Sci., v. 49, n. 5, p. 95-112, 2001.

YAMAUTI, M. S.; ALVES, P. L. C. A.; CARVALHO, L. B. Interações competitivas de triticale (Triticum turgidosecale) e nabiça (Raphanus raphanistrum) em função da população e proporção de plantas. Planta Daninha, v. 29, n. 1, p. 129135, 2011. 